\title{
Modeling flow, nutrient and dissolved oxygen concentrations in the Spokane River under multiple year conditions
}

\author{
Z. Rakib ${ }^{1}$, M. Barber ${ }^{1} \&$ R. Mahler ${ }^{2}$ \\ ${ }^{I}$ Civil and Environmental Engineering, University of Utah, USA \\ ${ }^{2}$ Soil Science Division, University of Idaho, USA
}

\begin{abstract}
Waste load allocations in the United States have traditionally been based on historic data. Total Maximum Daily Load (TMDL) policies and stormwater permits are often based on steady-state low flow analysis without considering unsteady flow and pollutant conditions prevalent during stormwater events. Questions surrounding remedial investments for conditions that don't exist during low flow events have been raised. Furthermore, the frequency of violations under various pollutant removal scenarios has been hard to determine.

The Spokane River TMDL used a 2001 low flow event as the basis for planning multi-million dollar investments in wastewater treatment systems and stormwater plans. This study modified the original CE-QUAL-W2 model to simulate hydrology and water quality over a 1999-2009 period with attention to flow, phosphorus, nitrogen, dissolved oxygen, and river temperature. By calibrating and applying the model for an extended period, we were able to better predict nutrient dynamics under varying flow conditions and facilitate investigation regarding permissible nutrient levels.

Model results indicate that hydrologic conditions outside the low flow period may be cause for concern. Violation of water quality standards occurred outside the 2001 time frame with both phosphorus and nitrate concentrations being much higher in years with higher flows. We were able to successfully demonstrate that additional information concerning stormwater inputs and nutrient cycling would permit better decisions in the future.

Keywords: Total Maximum Daily Loads, algal blooms, hydrodynamic simulation, waste load allocation, water quality modelling.
\end{abstract}




\section{Introduction}

It is widely recognized that pollution from both wastewater treatment facilities and stormwater runoff from impervious urban and suburban development can contribute to significant degradation of streams and rivers [1]. Numerous studies from around the world have linked human development to deteriorating stream conditions and the need for integrated approaches to wastewater and stormwater management [2-4]. Solution frameworks have also been proposed with varying complexities although few have actually been successfully implemented due to a wide variety of factors [5]. In the United States, such comprehensive plans are often associated with Total Maximum Daily Load (TMDL) studies and subsequent remediation plans (waste load allocation). Many of these studies have been performed using steady state models such as QUAL2Kw [6-8] owning to the fact that point sources were historically identified as both the main source and the main opportunity.

As the impacts of nutrient cycling, stream-aquifer interactions, and stormwater discharges becomes more widely recognized, infrastructure investments based on low flow, steady state conditions becomes harder to justify $[9,10]$. In the semiarid western United States this is particularly true since low flow conditions typically occur in August whereas stormwater loading occurs winter through early summer. However, examples of the growing importance of hydrodynamic water quality modeling from around the world have been increasing over the last decade [11].

This study used the Spokane River Basin in north eastern Washington, USA as the basis for evaluating the hypothesis that understanding unsteady flow and loading conditions over a variety of climate conditions will result in improved decision making capabilities. This study modified the original US Army Corps of Engineers CE-QUAL-W2 model [12] to simulate hydrology and water quality over a 10 year historic period (1999-2009), with particular attention to flow, phosphorus, nitrogen, dissolved oxygen, and river temperature. The model is a two-dimensional, laterally (width) averaged hydrodynamic flow and water quality code originally developed by the US Army Corps of Engineers. It was used to create the Spokane River dissolved oxygen TMDL which will require very low effluent CBOD $(4.2 \mathrm{mg} / \mathrm{l})$, ammonia nitrogen $(0.21 \mathrm{mg} / \mathrm{l})$, and total phosphorus $(0.042 \mathrm{mg} / \mathrm{l})$ concentrations in order to meet state water quality criteria [13]. In spite of these rather low concentrations, there are concerns that by picking a low flow year, the impacts of nonpoint sources may be misrepresented. By calibrating and applying the model for an extended period, we were able to better predict the nutrient dynamics under varying a variety of flow conditions and facilitate investigation and decisions regarding permissible nutrient levels that include a variety of hydrologic conditions.

\section{Background}

The Spokane River watershed, located in north eastern corner of the State of Washington, USA (Figure 1), consists of a series of river reaches and reservoirs 
created by the hydropower operations on the river. As a result of low summer flow conditions, sections of the river have been listed as impaired including Long Lake which has dissolved oxygen (DO) concentrations below beneficial use standards. In order to attain the DO requirement, significant reductions in nutrient loadings much be achieved. In the US, this is done through waste load allocation (WLA). WLA is the pollutant load allocated to current and future point sources (including Municipal Separate Storm Sewer System (MS4) and other permit-recognized nonpoint sources). It is part of the Total Maximum Daily Load (TMDL) calculation according to:

$$
\mathrm{TMDL}=\mathrm{WLA}+\mathrm{LA}+\mathrm{RC}+\mathrm{MOS}
$$

where LA are additional nonpoint sources, RC is reserve capacity for future growth, and MOS is margin of safety. Since TMDLs are typically triggered when water quality impairment has been identified, WLAs often require some amount of reduction in current loading which may involve installation of costly new or improved treatment systems or nonpoint source best management practices (BMPs).

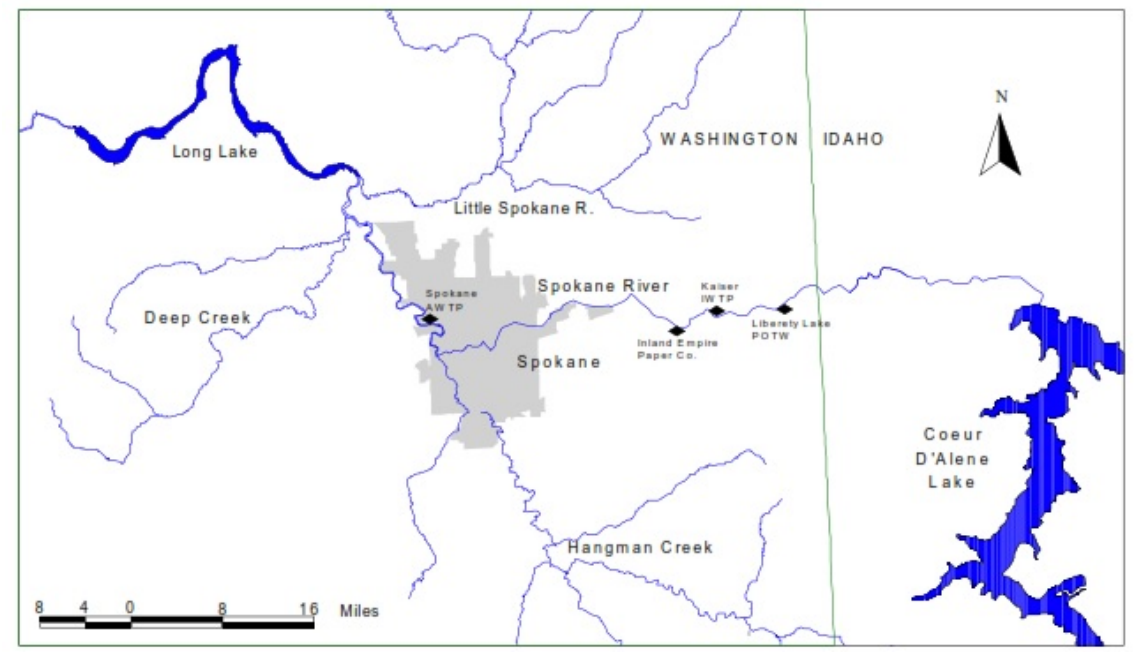

Figure 1: Spokane River Basin in north eastern Washington State, USA.

Although point sources have been regulated for some time, nonpoint sources have only been regulated by permit for a relatively short time. US legislation concerning stormwater was first passed as part of the 1987 Water Quality Act and Phase I National Pollutant Discharge Elimination System (NPDES) regulations were issued by the US Environmental Protection Agency (USEPA) in 1990 for municipal separate storm sewer systems (MS4s) serving populations over 100,000 and Phase II in 1999 for smaller MS4s located in "urbanized areas." Nevertheless, due to legal challenges and the need to identify, quantify, and assess stormwater 
quality information, many municipalities are just now dealing with issues surrounding implementation of plans for addressing urban nonpoint source pollution. In 2014 the US Government Accountability Office released a report recommending Congress consider revising the act's largely voluntary approach to restoring waters impaired by such pollution [14]. Granted some of the activities listed in Table 1 that are required as part of the MS4 permit (e.g. illicit discharges) will help existing water quality problems but many are still most enforceable during new design and construction.

Table 1: Minimum requirements of MS4 NPDES permit.

\begin{tabular}{|c|c|}
\hline Control Measures & Task \\
\hline 1. Education & $\begin{array}{l}\text { Distribute educational materials and perform outreach } \\
\text { to inform citizens about impacts of storm water runoff }\end{array}$ \\
\hline 2. Participation & $\begin{array}{l}\text { Provide opportunities for citizens to participate in } \\
\text { program development and implementation including } \\
\text { effectively publicizing public hearings and } \\
\text { encouraging citizen representation on storm water } \\
\text { management panels }\end{array}$ \\
\hline 3. Illicit discharges & $\begin{array}{l}\text { Develop/implement plan to detect/eliminate illicit } \\
\text { discharges that includes a system map and informing } \\
\text { the community about the hazards associated with } \\
\text { improper waste disposal }\end{array}$ \\
\hline 4. Construction & $\begin{array}{l}\text { Develop/enforce erosion and sediment control } \\
\text { program for construction activities that could include } \\
\text { silt fences and temporary detention ponds }\end{array}$ \\
\hline 5. Post-construction & $\begin{array}{l}\text { Develop/enforce a program to address discharges of } \\
\text { runoff from new development and redevelopment } \\
\text { areas. Controls could include preventative actions } \\
\text { such as protecting wetlands (sensitive areas) or using } \\
\text { structural BMPs such as grassed swales or porous } \\
\text { pavement }\end{array}$ \\
\hline 6. Good housekeeping & $\begin{array}{l}\text { Develop/implement a program with the goal of } \\
\text { preventing/reducing pollutant runoff from municipal } \\
\text { operations including municipal staff training on } \\
\text { pollution prevention techniques (e.g., street sweeping, } \\
\text { reduction of pesticide or street salt usage, or catch- } \\
\text { basin cleaning) }\end{array}$ \\
\hline
\end{tabular}


Implementing these controls effectively requires understanding the impact of both flows and quality on the ecosystem. A holistic integration of both wastewater and stormwater discharges have to be accounted for in the analysis particularly since in-stream retention and cycling of phosphorus concentrations has been linked to adverse ecological impacts [15]. Since stormwater discharges occur months or even years prior to low flow conditions, the use of steady state flow models may not capture the true impacts. Even when dynamic models are used, efforts generally focus on a low flow condition. Our hypothesis is that TMDLs developed using a model for a single low flow condition may not accurately reflect changes in the runoff cycle or nutrient cycling initiated by high flow years.

\section{Methodology}

This study modified the CE-QUAL-W2 model [12] to simulate hydrology and water quality over a 10 year historic period (1999-2009), with particular attention to flow, phosphorus, nitrogen, dissolved oxygen, and river temperature. The model begins (segment 1) at the Washington/Idaho state line (river mile 96.0) and extends downstream through segment 188 at the outlet of Long Lake (river mile 33.9). Overall, the model consisted of 188 longitudinal cells and an average of nearly 20 layers in the vertical direction.

The flow portion of the model was calibrated/validated using existing USGS gaging stations and known reservoir levels. In addition to the main flow entering from Post Falls Dam, tributary inflows from Hangman Creek, Little Spokane River, Coulee Creek, and wastewater discharges from the area were added. As the majority of dams on the river represented so-called "run of the river facilities", few adjustments had to be made for changing reservoir storage levels. Groundwater interactions, although significant sources/sinks of water, were assumed to be constant through each simulation year. Figures 2 and 3 illustrate a near perfect match between simulated flows and reported gage data due to our ability to fine tune operations.

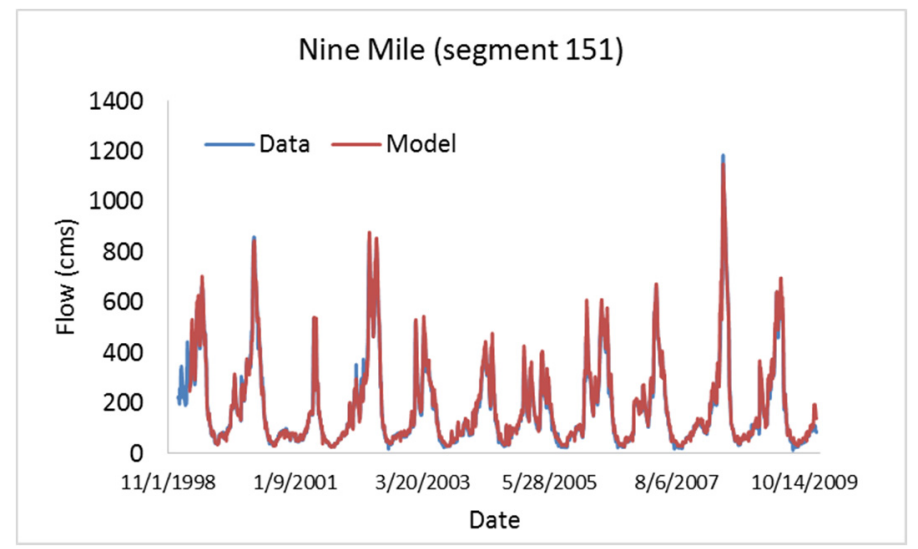

Figure 2: Example of calibration and validation flow results at segment 151. 


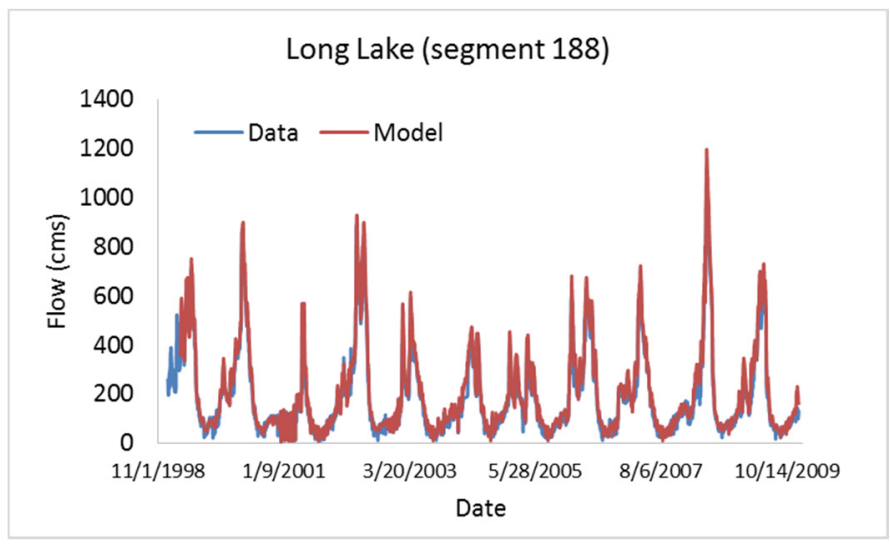

Figure 3: Example of calibration and validation flow results at segment 188.

Once the flow model successfully reproduced the 10 -year period the water quality portion of the model was calibrated and validated using data available from two distinct periods. Concentration data from State monitoring activities and reported WWTP discharges were used to examine the predictive capabilities of the model. Figures 4 and 5 depict temperature predictions and dissolved oxygen concentrations, respectively, from the Nine Mile (reservoir) pool located at river mile 58.1 along the Spokane River.

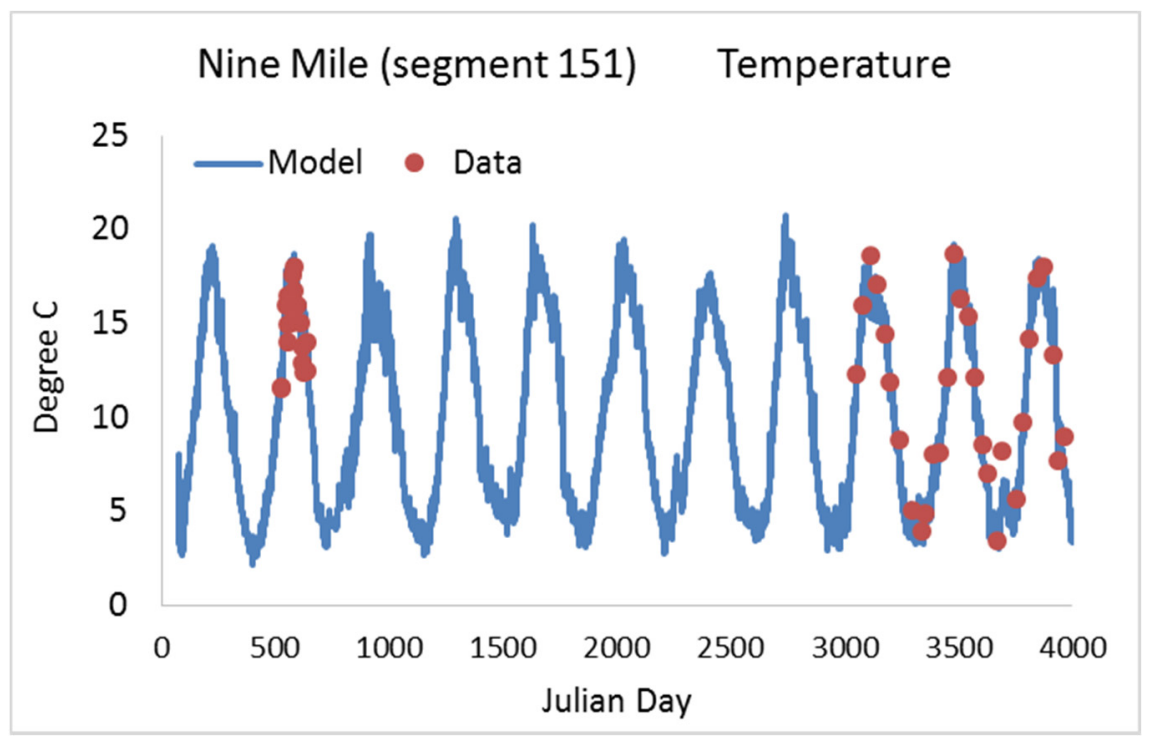

Figure 4: Calibration and validation results for modeled versus measured water temperatures at segment 151. 


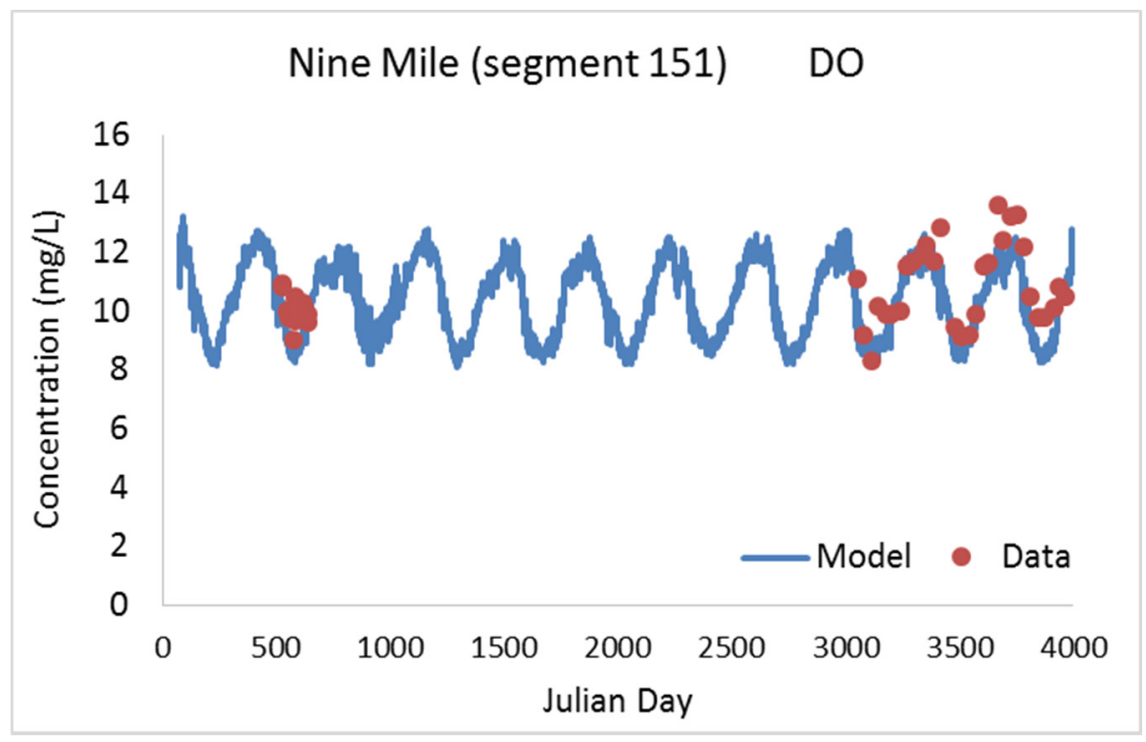

Figure 5: Calibration and validation results for modeled versus measured dissolved oxygen concentrations at segment 151 .

The water segment illustrated in Figures 4 and 5 does not represent the best or worse case for water quality; it is simply a location where measured values were available.

\section{Results and discussion}

Example output from the simulation period (3,944 days) are shown in the figures below. This period begins day 74 of 1999 and extends through the end of 2009. A snapshot of model outputs for phosphorus, ammonia, nitrate, dissolved oxygen, and temperature are shown. The seasonality of the snowmelt dominated watershed are clearly evident as is the effect of the upstream Lake Coeur D'Alene dampening of event peaks. Results from the model were examined with respect to state water quality standards. Particularly with respect to dissolved oxygen and temperature, we found many instances where predicted concentrations were in violation of state standards.

Furthermore, as we hypothesized, it is important to recognize that Figure 6 clearly shows higher phosphorus concentrations during water years 2007-2009 compared to 2001 (TMDL base year shown (Julian day 500+)). Similar patterns can be seen with other nutrients as well. Although the dissolved oxygen concentrations do not respond immediately, our results indicate the need to better understand nutrient cycling as periphyton and other algal growths may be stimulated by these constituents being available in the reservoirs. 


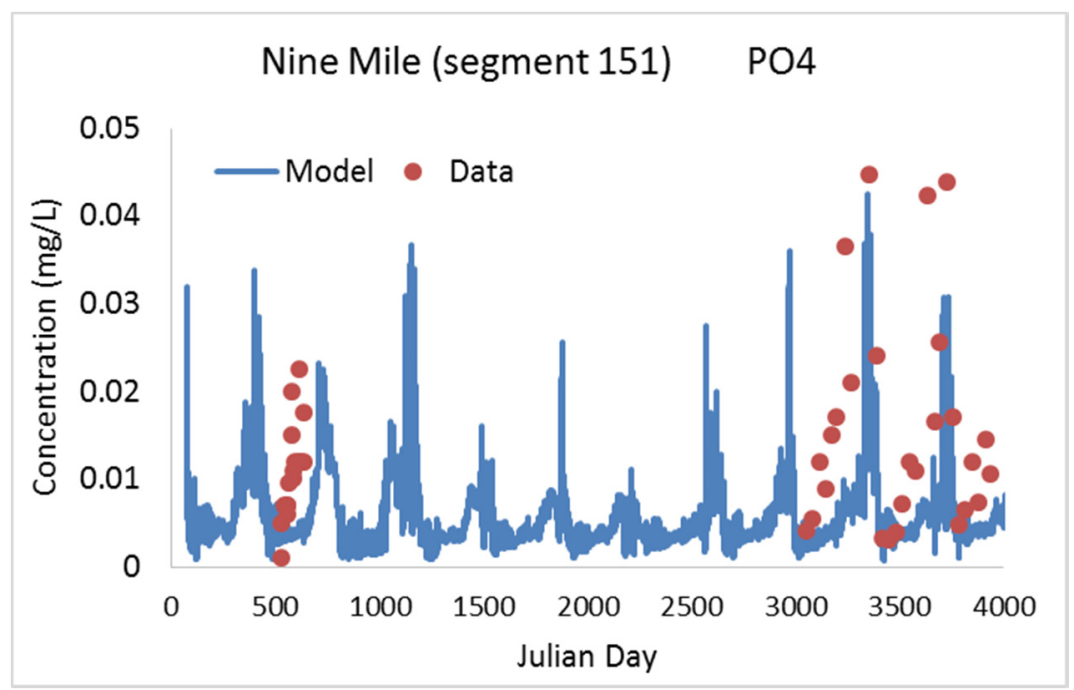

Figure 6: Modeled phosphorus concentrations at segment 151.

Figure 7 illustrates that ammonia concentrations generally at or near measurement thresholds in the system. This is fairly typical of many freshwater systems as nitrate (Figure 8) tends to be more prevalent. Figure 9 shows the dissolved oxygen (DO) calibration efforts.

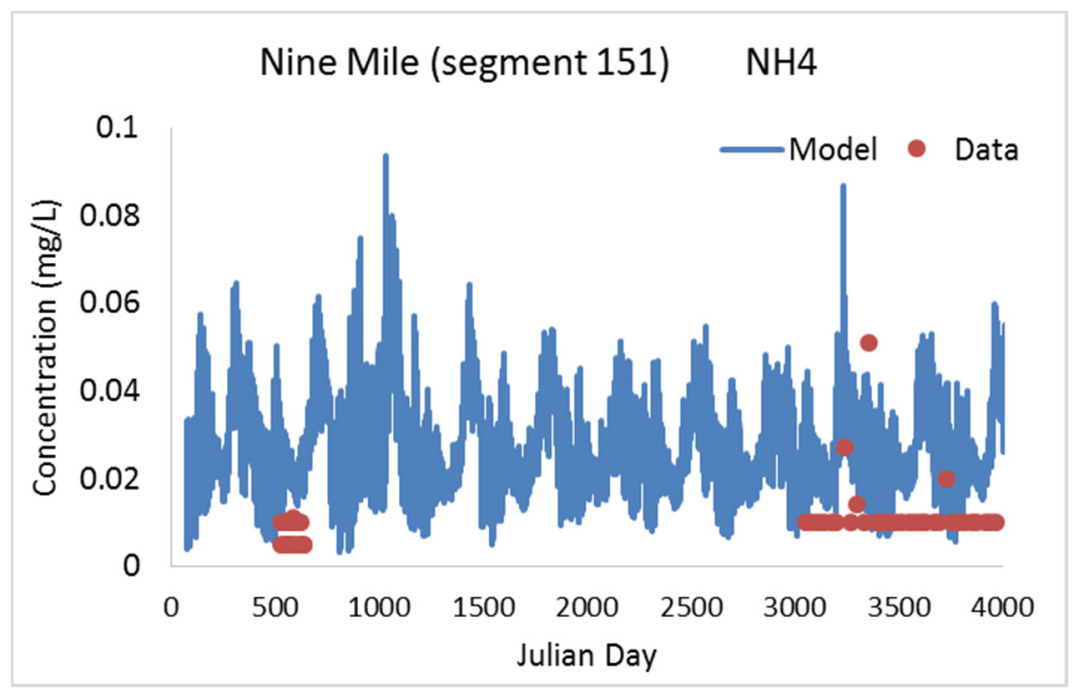

Figure 7: Modeled ammonia concentrations at segment 151. 


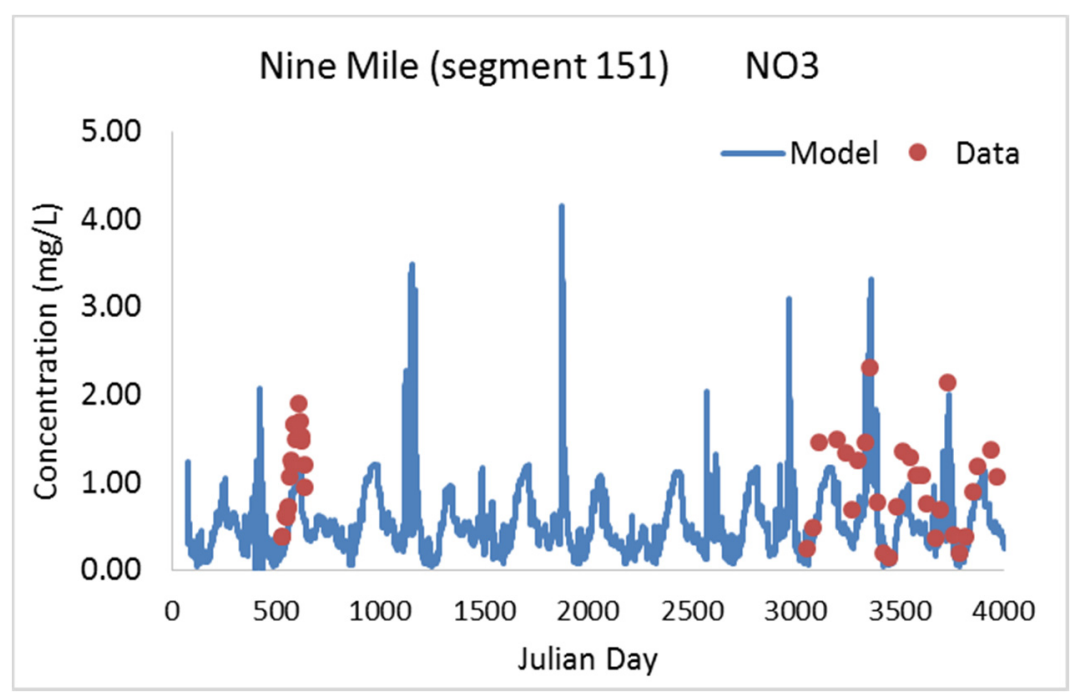

Figure 8: Modeled nitrate concentrations at segment 151.

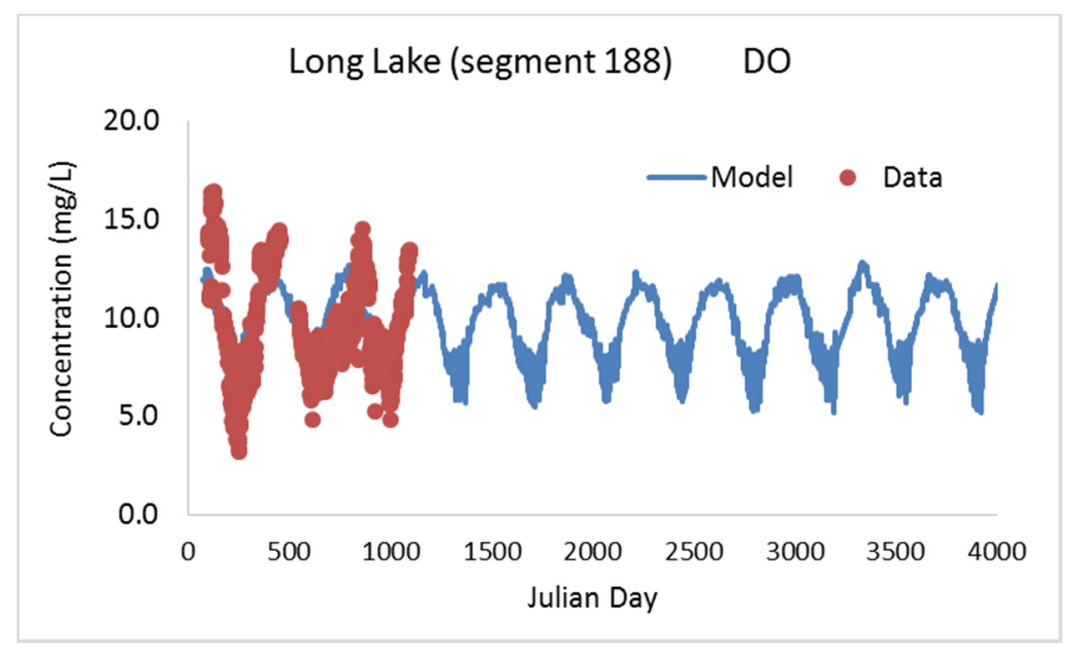

Figure 9: Modeled dissolved oxygen concentrations at Long Lake outlet.

Figure 10 illustrates the temperature in the downstream segment of the model at Long Lake. While 2001 represented a low flow year, predicted temperatures in other years were equally as bad as or worse than the TMDL year. The characteristics of hot, dry summer periods in the semi-arid western US leads to conditions that may be challenging from an ecosystem perspective regardless of spring runoff patterns. 


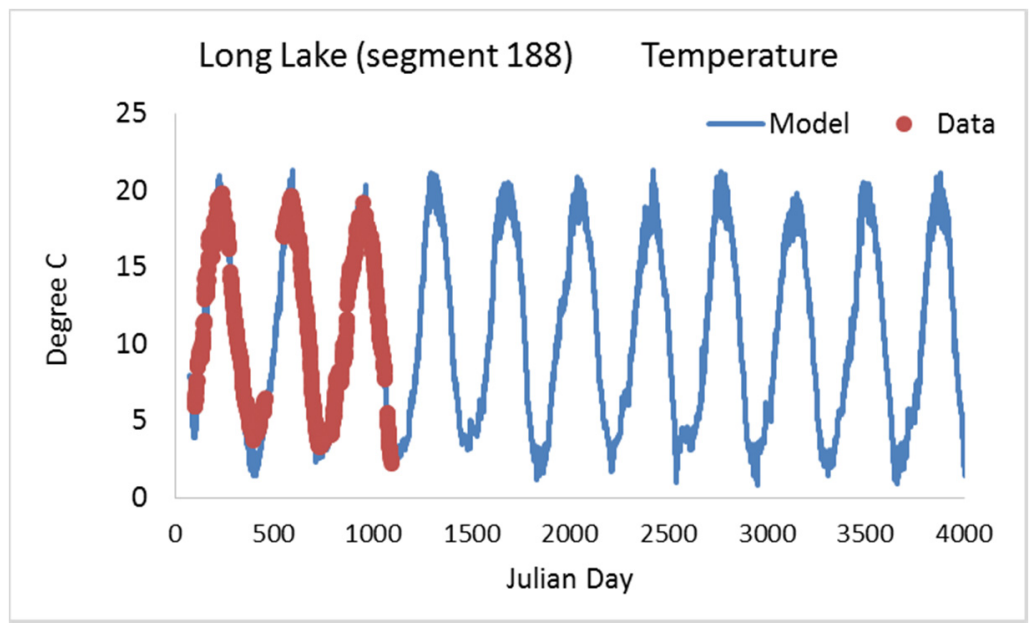

Figure 10: Modeled water temperatures at Long Lake outlet.

\section{Conclusions and recommendation}

The 2010 Dissolved Oxygen TMDL requires removal of more than 90 percent of total phosphorus at wastewater treatment plants and reductions of approximately 50 percent of nonpoint sources based on a low flow year. While this will require significant investment in the Spokane River system, our results indicate that it may not solve all the water quality problems. The role of stormwater on the waste load allocation process may have been unrepresented by the selection of a low flow year.

We were successfully able to calibrate the CE-QUAL-W2 model to historic flow and water quality concentrations over the simulation period. Adjusting boundary conditions and reservoir operations allowed a near perfect simulation of flow conditions. Water quality results illustrated more variability across all of pollutants of interest. The two-dimensional results indicate low dissolved oxygen concentrations at depth within Long Lake reservoir at times other than the 2001 low flow period. Thus, the impacts of nonpoint source loading and nutrient cycling thus remain significant concerns.

During calibration it became apparent that while point sources from waste water treatment facilities were well known, the model proved to be fairly sensitive to nonpoint loadings for which data were sparse. Variability of stormwater pollutant flows and concentrations need more data. In addition, groundwater contributions to nutrient loading were held constant over the 10 year period which may need to be adjusted in the future if more data is acquired.

Refinement of the model are continuing looking at sensitivities and techniques for estimating nonpoint loading. There are also still important questions to address regarding future impacts of population growth, technology improvements, and climate change. This model can be used to help answer these types of questions as well. 


\section{Acknowledgement}

This project was funded by the United State Department of Agriculture National Institute of Food and Agriculture through their AFRI Climate Change program.

\section{References}

[1] US Environmental Protection Agency. National management measures to control nonpoint source pollution from urban areas. EPA-8410B-05-004, Office of Water, Washington, DC. 2005.

[2] Paul, M.J. \& Meyer, J.L. Streams in the urban landscape. Annual Review of Ecology and Systematics, 32, pp. 333-365, 2001.

[3] Martin, C., Rupert, Y., \& Legret, M. Urban stormwater drainage management: the development of a multicriteria decision aid approach for best management practices. European Journal of Operation Research, 181(1), pp. 338-349, 2006.

[4] Rauch, W., Seggelke, K., Brown, R., \& Krebs, P. Integrated approaches in urban storm drainage: where do we stand? Environmental Management, 35(4), pp. 396-409, 2005.

[5] Pearson, L.J., Coggan, A., Proctor, W., \& Smith, T.F. A sustainable decision support framework for urban water management. Water Resources Management, 24(2), pp. 363-376, 2010.

[6] Pelletier, G.J., Chapra, S.C., \& Hua, T., QUAL2Kw e A framework for modeling water quality in streams and rivers using a genetic algorithm for calibration. Environmental Modelling and Software, 21, pp. 419-425, 2006.

[7] Turner, D., Pelletier, G., \& Kasper, B., Dissolved oxygen and pH modeling of a periphyton dominated, nutrient enriched river. ASCE Journal of Environmental Engineering, 135(8), pp. 645-652, 2009.

[8] Neilson, B.T., Hobson, A.J., Vonstackelberg, N., Shupryt, M., \& Ostenmiller, J., Using Qual2K modeling to support nutrient criteria development and wasteload analyses in Utah. Final Project Report. Utah Department of Environmental Quality. Division of Water Quality. Salt Lake City, UT, 2012.

[9] Bellucci, C., Stormwater and aquatic life: making the connection between impervious cover and aquatic life impairments for TMDL development in Connecticut streams. Proceedings of the Water Environment Federation, pp. 1003-1018, 2007.

[10] Saleh, F., Flipo, N., Habets, F., Ducharne, A., Oudin, L., Viennot, P., \& Ledoux, E., Modeling the impact of in-stream water level fluctuations on stream-aquifer interactions at the regional scale. Journal of Hydrology, 400(3-4), pp. 490-500, 2011.

[11] Kacikoc, M., \& Beyhan, M., Hydrodynamic and water quality modeling of Lake Egirdir. Clean - Soil Air Water, 42(9999), pp. 1-10, 2014.

[12] Cole, T.M., \& Wells, S.A. CE-QUAL-W2: a two-dimensional, laterally averaged, hydrodynamic and water quality model, version 3.6. Department 
of Civil and Environmental Engineering, Portland State University, Portland, OR. http://www.cee.pdx.edu/w2/

[13] Clark, D.L., Kasch, M., \& Brattebo, B., Spokane River watershed strategies for point and nonpoint source management to meet the most restrictive TMDL in the nation. Proceeding of the Water Environment Federation, pp. 632-640, 2011.

[14] US Government Accountability Office. Clean Water Act: changes needed if key EPA program is to help fulfil the nation's water quality goals. GAO14-80, Washington, DC, p. 108, 2014.

[15] Withers, P.J.A., \& Jarvie, H.P. Delivery and cycling of phosphorus in rivers: a review. Science of the Total Environment, 400(1-3), pp. 379-395, 2008. 